\title{
ПОРІВНЯЛЬНИЙ АНАЛІЗ ЕКОНОМІКИ УКРАЇНИ ТА РЕЕR-ГРУПИ КРАЇН НА ПЕРІОДІ 1990-2014 РОКІВ
}

\author{
СРАВНИТЕЛЬНЫЙ АНАЛИЗ ЭКОНОМИКИ УКРАИНЫ И РЕЕR-ГРУППЫ \\ СТРАН В ПЕРИОД 1990-2014 ГОДОВ
}

\section{COMPARATIVE ANALYSIS OF THE ECONOMIES OF UKRAINE AND ITS PEER- COUNTRIES DURING 1990-2014}

\begin{abstract}
Визначено позиції країн за окремими макроекономічними показниками для Украӥни та інших краӥн (реег-групи - групи країн, які мали близькі до Украӥни обсяги ВВП на одну особу у 1990 рочі). Здійснено порівняльний аналіз за абсолютними та відносними показниками ВВП і промислового виробниџтва. Приведено місце Украйни у світовій економіці у 1990 та 2014 роках. Проаналізовано зміни в економіках краӥн реег-групи за період 25 років. Висунута гіпотеза про те, щзо проінформованість про місце України у глобальному сочіально-економічному просторі, аналізування основних макроекономічних показників, індексів та індикаторів, надання рекомендачій органам державної влади стосовно розробки та реалізаиї управлінських рімень на державному рівні з приводу поліпшення національної економіки спроможне підняти рівень якості та безпеки життя в Украӥні. Здійснено візуалізацію змін обсягу ВВП на особу за період 1990-2015 роки для України та країн реег-групи. Виявлено ближчих «сусідів» за окремими макроекономічними показниками. Запропоновано методичний підхід до здійснення компаративного аналізу реег-групи об'єктів /у намому випадку країн/ на значному відтинку часу за одним з макроекономічних показників.
\end{abstract}

Ключові слова: економіка країн, ВВП, peеr-група, ВВП на одну особу

Определены позищии стран по отдельным макроэкономическим показателям для Украины и других стран (реег-группь - группь стран, которые имели близкие к Украине объемы ВВП на душу населения в 1990 году). Осуществлен сравнительный анализ по абсолютным и относительным показателям ВВП и промышленному производству. Приведено место Украины в мировой экономике в 1990 и 2014 годах. Проанализировано изменения в экономиках стран реег-группы за период 25 лет. Выдвинута гипотеза о том, что осведомленность о месте Украины в глобальном социально-экономическом пространстве, анализ основных макроэкономических показателей, индексов $и$ индикаторов, предоставление рекомендащий органам государственной власти по разработке и реализации управленческих решений на государственном уровне по поводу улучшения национальной экономики способно поднять уровень качества и безопасности жизни в Украине. Осуществлено визуализаџию изменений объема ВВП на душу за период 1990-2015 годы для Украины и стран peег-группьл. Выявлено более близких «соседей» по отдельным макроэкономическим показателям. Предложен методический подход к осуществлению сравнительного анализа реег-группь объектов /в нашем случае стран/на значительном отрезке времени с одним из макроэкономических показателей.

Ключевые слова: экономика стран, ВВП, реег-группа, ВВП на душу населения 
This research covers the analysis of Ukraine and its peer-countries as based on certain macroeconomic criteria, specifically the GDP per capita in 1990. A study includes a comparative analysis of the absolute and relative characteristics of the GDP and industrial output: the authors analyze a Ukraine's position in the world economy. The changes in the countries' economies have been investigated into in the research. The authors deem that the awareness about the Ukraine's position in the global social and economic environment, analysis of macroeconomic factors, indices and indicators, recommendations to state authorities regarding the development and implementation of managerial decisions aimed at improvement of the national economy at the state level can raise the living and security standards in the country. The research represents a visualization of the GDP per capita for Ukraine and peercountries during the period of 1990-2015 and categorizes the "neighbouring" countries as based on macroeconomic criteria. The authors elaborate on the methodic approach to the peercountries comparative analysis, which includes a time range and a specific macroeconomic factor.

Keywords: economy countries, GDP, peer-group, GDP per capita

Вступ. Україна у 1990 році за показником «ВВП на одну особу» посідала 94 місце з 183 країн, а в 2014 році вже опустилася на 129 позицію 3 188 країн, за якими доступні дані. За абсолютним значенням у 2014 році Україна мала 60 позицію з 187 країн. Це у 400 разів менше, аніж всі разом високо розвинуті країни (High income). ВВП України у понад 140 разів менше, ніж ВВП всіх країн Свросоюзу та більше аніж в 100 разів менше країн єврозони. Розглядаючи «сусідів» за обсягами ВВП (Україна - 60 позиція з 187 країн) маємо такий перелік країн: дещо вище України знаходиться Бангладеш, Кувейт, Угорщина; дещо нижче Марокко, Еквадор, Словаччина.

Стосовно відносних значень, то внесок України у виробництво промислових товарів складав у 1991 році 0,57\%, а вже у 2013 році всього 0,20 \%, тоді як Російська Федерація практично не змінила частку 3,2 \% та 3,0 \% відповідно. Досить значним зростанням відзначився Китай з 2,1 \% до 19,2 \%. А от окремі країни «G7» знизили свої частки: Німеччина з 8,4 \% до 4,8 \%, Франція 3 4,1 \% до 2,1 \%, Італія 3 4,5 \% до 2,1 \%, Японія 3 17,8 \% до 6,0 \%.

За 25 років (з 1990 по 2014 рік) «здобутки» України мали за показником «ВВП за ринковими цінами» зростання всього у 1,6 рази, а весь світ за цей же період «виріс» у 3,5 рази. За цим показником Україна мала 0,36 \% світової економіки, а в 2014 році всього 0,17\%. Це при тому, що Україна $є$ 139 країн з повним циклу виробництва літаків [1, с. 427], в країні наявні значні ресурси (23 \% європейських і 3 \% світових чорноземів) [2, с. 159], а за 1989-1995 роки Україна посідала 1 місце за показником «Науковий кадровий потенціал» [3, с. 25]. А 3120 корисних копалин, що використовуються людством, промислові обсяги в Україні є 94 види і враховуються Державним балансом запасів [4, с. 8].

Постановка завдання. Стабільне функціонування національної економіки у світовій та повернення через деякий час тих позицій, які були стартовими для України у 1990 році потребує значних зусиль на державному рівні та належного наукового обгрунтування стратегій розвитку, які базуються на досвіді багатьох країн. Зазначимо ще те, що економіка України 
в 1990 році становила 0,36 \% від світової, в 2014 році - 0,17\%, а в 2015 всього $0,12 \%$. Це при тому, що маємо 63 місце у рейтингу за цим показником серед 195 країн, що досліджувалися. Саме тому виникає нагальна потреба у дослідженні, яке носить системний та комплексний характер i надає можливість узагальнити напрацювання та надати рекомендації стосовно зміни ситуації.

Нами висувається гіпотеза про те, що проінформованість про місце України у глобальному соціально-економічному просторі, аналізування основних макроекономічних показників, індексів та індикаторів, надання рекомендацій органам державної влади стосовно розробки та реалізації управлінських рішень на державному рівні 3 приводу поліпшення національної економіки спроможне підняти рівень якості та безпеки життя в Україні. Зазначене може бути реалізовано у тому числі з використанням положень концепції сталого розвитку.

Науковою проблемою є розробка практичних рекомендації стосовно економічного розвитку країни на основі об'єктивного порівняння та оцінювання макроекономічних показників, індексів та індикаторів на значному відтинку часу з врахуванням змін, що відбуваються у економічній системі світу за тривалий час.

Основними завданнями статті $є$ наступне: визначення peer-групи країни, які у 1990 році за показником ВВП на одну особу мали досить близькі значення; аналізування зміни частки промислового виробництва; дослідження величини зміни показника на відтинках часу 1990-2014pp., 1990-2015 pp., 2014-2015 рр.; зробити висновки за здійсненим аналізом досліджуваних величин.

Методологія. Теоретичну основу дослідження складають наукові підходи до рейтингування країн за макроекономічними показниками, виявлення критичних i низьких значень показників. Методологічною основою наукового дослідження обрано методи порівняльного аналізу, логічного узагальнення, рейтингування.

Базою для дослідження $є$ статистичні дані макроекономічних показників [5], а також індексів та індикаторів [6], що використовуються у розрахунку показників сталого розвитку для України та інших країн. Значний обсяг даних при аналізуванні привів до зумисних обмежень, нами виділена peer-група, тобто обрано країни, які у 1990 році за показником ВВП мали досить близькі значення. Такими країнами визначено (за алфавітом): Азербайджан; Албанія; Болгарія; Вірменія; Греція; Грузія; Казахстан; Киргизька Республіка; Китай; Кіпр; Македонія; Молдова; Польща; Російська Федерація; Румунія; Словаччина; Туреччина; Україна; Чеська Республіка, а також для порівняння взято значення показника для ЕС та для країн зони євро.

Результати дослідження. Стосовно основи економічного розвитку промислового виробництва, то внесок промисловості у ВВП України знизився з 50,9 \% у 1992 році до 25,4 \% у 2014 році. Тоді як країни «Великої Сімки» за період від 1997 року по 2014 рік (доступні дані) мали від 19,4 \% до 
38,1 \%. Зазначимо, що на 1992 рік Франція мала 26,2 \%, Італія - 29,4 \%, Японія - 36,5 \%, Великобританія - 30,3 \%. Варто відзначити Китай, який впродовж 1990-2014 роки має значення цього показника від 40,9 \% до 47,9 \% внеску промисловості у ВВП.

Стосовно peer-групи для України на той період маємо те, що жодна із країн не мала такого значного потенціалу промисловості: Білорусь - 47,8 \%, Казахстан - 44,6 \%, Болгарія - 43,5 \%, Румунія - 44,0 \%, Російська Федерація $43,0 \%$ та Китай по 43,0 \%. Інші країни цієї групи мали значення, що було нижче 40 \% (за зниженням значення показника): Азербайджан - 39,9 \%; Вірменія - 39,4 \%; Македонія - 39,1 \%; Киргизія - 37,8 \%; Узбекистан - 35,8 $\%$; Туреччина - 32,4 \%; Молдова - 31,5\%; Великобританія - 30,8 \%; Італія 29,3 \%; Грузія - 23,9 \%; Албанія - 23,3 \%; Франція 26,2 \%; Туркменія 11,9 \%. Окремо виділимо Японію - 36,5 \%, Німеччину - 35,9 \%, Великобританію $30,8 \%$ та Італію - 29,3\%.

Значення обсягів ВВП на одну особу у 1990, 2014, та у 2015 роках, а також відношення значень показника 2014 та 2015 років до 1990 року приведена у таблиці.

Таблиия

Обсяги ВВП на особу за період 1990-2014 роки для України, країн peer-групи та інших суб'єктів

\begin{tabular}{|c|c|c|c|c|c|c|}
\hline $\begin{array}{l}\text { Код } \\
\text { країни }\end{array}$ & $\begin{array}{c}\text { ВВП } \\
\text { на } \\
\text { особу } \\
\text { за } \\
1990 \\
\text { рік, } \\
\text { дол. }\end{array}$ & $\begin{array}{c}\text { ВВП } \\
\text { на } \\
\text { особу } \\
\text { за } \\
2014 \\
\text { рік, } \\
\text { дол. }\end{array}$ & $\begin{array}{c}\text { ВВП } \\
\text { на } \\
\text { особу } \\
\text { за } \\
2015 \\
\text { рік, } \\
\text { дол. }\end{array}$ & $\begin{array}{c}\text { Відношення } \\
2014 \text { року } \\
\text { до } 1990 \\
\text { року }\end{array}$ & $\begin{array}{c}\text { Відношення } \\
2015 \text { року } \\
\text { до } 1990 \\
\text { року }\end{array}$ & $\begin{array}{c}\text { Відношення } \\
2015 \text { року } \\
\text { до } 2014 \\
\text { року }\end{array}$ \\
\hline EMU & 18853 & 39589 & 33998 & 2,100 & 1,803 & 0,859 \\
\hline EUU & 15854 & 36423 & 31843 & 2,297 & 2,009 & 0,874 \\
\hline CYP & 9642 & 27194 & 22957 & 2,821 & 2,381 & 0,844 \\
\hline GRC & 9638 & 21498 & 18036 & 2,231 & 1,871 & 0,839 \\
\hline WLD & 4267 & 10721 & 9996 & 2,513 & 2,342 & 0,932 \\
\hline CZE & 3902 & 19530 & 17231 & 5,006 & 4,417 & 0,882 \\
\hline RUS & 3485 & 12736 & 9057 & 3,654 & 2,599 & 0,711 \\
\hline TUR & 2791 & 10515 & 9130 & 3,768 & 3,272 & 0,868 \\
\hline SVK & 2396 & 18501 & 15963 & 7,723 & 6,663 & 0,863 \\
\hline BGR & 2377 & 7851 & 6820 & 3,303 & 2,869 & 0,869 \\
\hline CEB & 2297 & 14087 & 12323 & 6,132 & 5,364 & 0,875 \\
\hline MKD & 2240 & 5456 & 4853 & 2,435 & 2,166 & 0,889 \\
\hline BLR & 1705 & 8040 & 5740 & 4,716 & 3,367 & 0,714 \\
\hline POL & 1698 & 14343 & 12494 & 8,447 & 7,358 & 0,871 \\
\hline ROM & 1651 & 9997 & 10508 & 6,056 & 6,366 & 1,051 \\
\hline KAZ & 1647 & 12602 & 10508 & 7,649 & 6,379 & 0,834 \\
\hline
\end{tabular}




\begin{tabular}{|c|c|c|c|c|c|c|}
\hline GEO & 1615 & 3670 & 3796 & 2,273 & 2,351 & 1,034 \\
\hline UKR & 1570 & 3082 & 2115 & 1,964 & 1,347 & 0,686 \\
\hline AZE & 1237 & 7884 & 5496 & 6,372 & 4,442 & 0,697 \\
\hline MDA & 972 & 2239 & 1843 & 2,303 & 1,896 & 0,823 \\
\hline TKM & 881 & 9032 & 6948 & 10,250 & 7,885 & 0,769 \\
\hline UZB & 651 & 2037 & 2132 & 3,127 & 3,273 & 1,047 \\
\hline ALB & 639 & 4564 & 3965 & 7,138 & 6,201 & 0,869 \\
\hline ARM & 637 & 3874 & 3500 & 6,084 & 5,497 & 0,904 \\
\hline KGZ & 609 & 1269 & 1103 & 2,084 & 1,812 & 0,869 \\
\hline CHN & 316 & 7590 & 7925 & 24,002 & 25,060 & 1,044 \\
\hline
\end{tabular}

Маємо те, що зростання для України несуттєві для 2014 року та нижче одиниці для 2015 року відносно 1990 року. Окремі країни зробили значний стрибок у розвитку за цей період: країни Євросоюзу у 2,3 (2,0 у 2015 році) рази, зокрема Польща в $8,4(7,4)$ рази, Словаччина у $7,7(6,7)$ рази, Румунія у $6,1(6,4)$ рази, Чехія у $5,0(4,4)$ разів, Болгарія у $3,3(2,7)$ рази, Кіпр у $2,8(2,4)$ рази, Греція у 2,2 $(1,8)$ рази. Країни СРСР також дещо випереджають розвиток України за цей період: Туркменія у 10,2 $(7,9)$ рази, Казахстан у 7,6 $(6,4)$ рази, Азербайджан у $6,3(4,4)$ рази, Вірменія у $6,1(5,5)$ рази, Білорусь у $4,7(3,4)$ рази, Російська Федерація у $3,7(2,6)$ рази, Узбекистан у $3,1(3,3)$ рази, Молдова у 2,3 $(1,9)$ рази, Киргизія у $2,1(1,8)$ рази. Зазначимо, що ці країни мали однакові стартові позиції на початку 90-их років XX століття. Доцільно виокремити Китай, який за цей період ВВП на одну особу у цій країні зросло у 24 (25 для відношення значень 2015 року до 1990 року) рази.

На рисунку наведено зміну обсягу ВВП на особу (дол. США) за період 1990-2015 роки для України та країн реer-групи (групи країн, які мали близькі до України обсяги ВВП на одну особу).

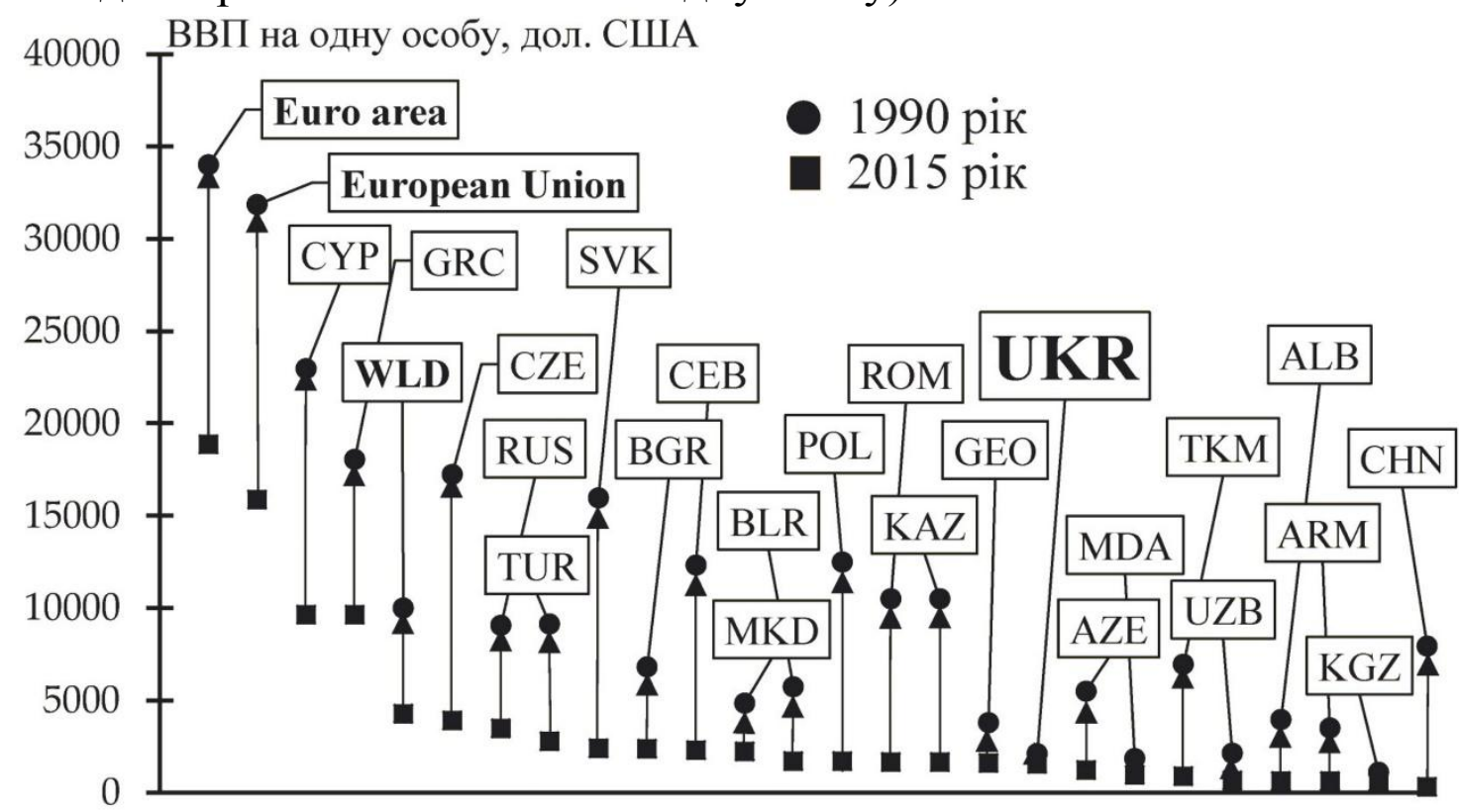

Рисунок. Зміна обсягу ВВП на одну особу за період 1990-2015 роки для України та країн peer-групи 
Загалом у світі цей показник за 25 років показав зростання на $250 \%$, а Україна всього на 196,3 \%, значно поступаючи всім країнам peer-групи. Маємо те, що зростання для України несуттєві. Окремі країни зробили значний стрибок у розвитку за цей період.

За абсолютним значенням у 1990 році ВВП України було на 178 місці 3 184 країн, а в 2014 році вже 603194 країн (0,17\% від світового). За показником ВВП на одну особу у 1990 році Україна посідала 109 позицію 3 211 країн, за якими доступний цей показник. Проте маємо 148 позицію 3215 країн, за якими доступні дані за 2014 рік. У 400 разів менше, аніж всі високо розвинуті країни (High income). ВВП України у понад 140 разів менше, ніж ВВП всіх країн Євросоюзу та більше 100 разів єврозони. [5]. Розглядаючи «сусідів» за обсягами ВВП маємо такий перелік країн: дещо вище України знаходиться Бангладеш, Кувейт, Угорщина; дещо нижче Марокко, Еквадор, Словаччина. До 2000 року в результаті постійної рецесії номінальний валовий внутрішній продукт країни склав 38,3 \% від 1990 року у доларовому вираженні (показник «GDP at market prices»).

Висновки. На підставі проведеного аналізу з використанням значень окремих макроекономічних показників зроблені такі висновки: 1) за 25 років за показником «ВВП на одну особу» Україна знизилася з 94 позиції на 129 позицію у рейтингу; 2) національна економіка України - це близько 1/400 від ВВП високо розвинутих країн (High income), 1/140 разів ВВП всіх країн Євросоюзу та 1/100 країн єврозони; 3) виробництво промислових товарів Україною у 1991 році становило близько 1/175 від загально світового, а в 2013 році вже 1/500; 4) з 1990 по 2014 рік Україна за показником «ВВП за ринковими цінами» зросла всього у 1,6 рази (країни світу у середньому у 3,5 рази); 5) на тепер Україна - це 1/830 економіки світу на противагу 1990 року - 1/280 частка; 6) за 25 років зниження промислового виробництва становило з близько 50 \% до 25 натепер; 7) для peer-групи (у нашому випадку для країн 3 подібним рівнем економіки на 1990 рік) характерним $є$ незначне зростання (до 8 разів) окрім Китаю (у 25 разів).

Таким чином на основі аналізу показників peer-група виявлено стан, зміну та місце України серед подібних країн на 1990 рік. Запропонований методичний підхід до здійснення компаративного аналізу реег-групи об'єктів /у нашому випадку країн/ на значному відтинку часу за одним 3 макроекономічних показників /у нашому випадку ВВП на одну особу/ (наукова новизна) надав змогу виявити місце та можливості країни у межах обраної реer-групи.

Подальші наукові дослідження можливі у визначенні перспективних для країни напрямів розвитку з врахуванням місця країни у межах peerгрупи.

\section{Література:}

1. Горбачова О. М. Аналіз ефективності діяльності підприємств авіабудівної галузі України на сучасному етапі [Електронне видання] / О. М. Горбачова, В. М. Ковтуненко // Глобальні та національні проблеми економіки : електронне фахове видання 
Миколаївського нац. ун-тету ім. В. О. Сухомлинського. - Миколаїв. - Вип. 4 (2015). - С. 427-430. - Режим доступу : http://www.global-national.in.ua/archive/4-2015/90.pdf

2. Стефанків О. М. Раціоналізація природокористування в АПК та формування екологічної свідомості населення : моногр. / О. М. Стефанків, О. М. Максимович - ІваноФранківськ : Сімик, 2012. - 180 с.

3. Інноваційний потенціал України: стан, тенденції i проблеми розвитку : аналітична доповідь / Національна безпека і оборона : журнал Центру Разумкова, 2004. № $7 .-25 \mathrm{c}$.

4. Традиційні та нетрадиційні системи енергозабезпечення урбанізованих i промислових територій України: моногр. / Г. Г. Півняк, О. С. Бешта, М. М. Табаченко та ін.; під заг. ред. Г. Г. Півняка. - Д. : Національний гірничий університет, 2013. - 333 с.

5. Офіційний сайт The World Bank. Data \& Research. [Electronic Resource] - Mode of access : http://data.worldbank.org/

6. База даних Світового центру даних 3 геоінформатики та сталого розвитку [Електронний ресурс]. - Режим доступу : http://wdc.org.ua/uk/data 